folk/ed. Derg, 2021; 27(4)-108. sayı

DOI: $10.22559 /$ folklor.1875

\title{
Yaşar Kemal'in Demirciler Çarşısı Cinayeti ve Yusufçuk Yusuf Romanlarında Hegemonik Erkeklik
}

\author{
Hegemonic Masculinity in Yaşar Kemal's \\ Demirciler Çarşısı Cinayeti and Yusufçuk Yusuf Novels
}

\section{Aziz Şeker* Emre Özcan ${ }^{* *}$}

\begin{abstract}
Öz
Sosyal bilimler literatüründe son yıllarda toplumsal cinsiyet yaklaşımlarının yaygınlaşmasıyla erkeklik olgusu, sosyoloji ve kültürel antropoloji disiplinlerinin önemli konularından biri hâline gelmiştir. Bununla birlikte edebiyat ve edebiyat sosyolojisi içerisindeki çalışmalarda da ataerkillik, toplumsal cinsiyet eşitsizliği, eril tahakküm ve erkeklik gibi kavramsallaştırmalar üzerinden analizler hız kazanmıştır. Özellikle toplumsal gerçekliği; kültürel, politik ve ekonomik koşullar etrafında işleyebilen romanların edebiyat sosyolojisi için ciddi bir inceleme nes-
\end{abstract}

Geliş tarihi (Received): 10-06-2021 - Kabul tarihi (Accepted): 17-09-2021

* Doç. Dr., Amasya Üniversitesi Rektörlüğ̈̈. shuaziz@ gmail.com. ORCID 0000-0001-5634-0221

** Dr., Ankara Başkent Üniversitesi Sağlık Bilimleri Fakültesi.Ankara Baskent University Faculty of Health Sciences emreozcan8747@gmail.com. ORCID 0000-0002-0877-2457 
nesi olduğu dikkate alındığında, bu kavramsallaştırmaların neden öne çıktığı anlaşılabilmektedir. Nihayetinde edebiyat, toplumsal tarihin dişında özerk bir sahaya karşılık gelmediği gibi erkeklik gerçeği de bu tarihe dişsal değildir. Çağdaş Türk edebiyatının önemli temsilcilerinden Yaşar Kemal eserlerinde içinde bulunduğu dönemin toplumsal, kültürel yapısını ve üretim ilişkilerini kendine özgü üslubuyla okura sunar. Yapıtlarındaki erkeklik olgusu ise özellikle Çukurova bölgesi üzerinden çözümlediği sosyo-ekonomik, kültürel ve politik yapı ile insan ilişkilerini boydan boya kesen önemli bir konu olarak ortaya çıkmaktadır. Bu noktadan hareketle, çalışmada onun Demirciler Çarşısı Cinayeti ve Yusufçuk Yusuf adlarıyla iki ciltten oluşan Akçasazın Ağaları eseri hegemonik erkeklik olgusu çerçevesinde tartışılacaktır.

Anahtar sözcükler: edebiyat sosyolojisi, kültürel antropoloji, toplumsal cinsiyet, hegemonik erkeklik, Yaşar Kemal

\begin{abstract}
In recent years, with the widespread use of gender approaches in the literature of social sciences, the phenomenon of masculinity has become one of the central issues of the disciplines of sociology and cultural anthropology. In addition, in studies within the sociology of literature and literature, analyzes have gained momentum via conceptualizations such as patriarchy, gender inequality, masculine domination, and masculinity. Considering that novels, which can work on social reality around cultural, political and economic conditions, are a serious object of study for the sociology of literature, it can be understood why these conceptualizations come to the fore front. Eventually, literature does not correspond to an autonomous field outside of social history, and the reality of masculinity is not external to this history. Yaşar Kemal, one of the important representatives of modern Turkish literature, presents the social and cultural structure and relations of production of the period to the reader in his own unique style. The phenomenon of masculinity emerges as the junction point of socio-economic, cultural and political structure and human relations, which it analyzes especially through the Çukurova region. From this point of view, in this study, his novel Akçasazın A ̆galarl, in which consists of two volumes as Demirciler Çarşısı Cinayeti and Yusufçuk Yusuf, opens to a discussion within the framework of hegemonic masculinity.
\end{abstract}

Keywords: sociology of literature, cultural anthropology, gender, hegemonic masculinity, Yaşar Kemal

\title{
Extended summary
}

While studies evaluating the phenomenon of gender through the emphasis on masculinityas a sociological and anthropological field have gained a place in the social sciences literature in recent years, it is possible to say that masculinity studies also receive the attention it deserves in literature. The positioning of masculinity representations in Turkish literature through dominant characters is the beginning of the 2000s. It is seen that masculinity performances in literary texts have become one of the important tools in the reproduction of masculinity norms and practices. 
In the novels of Yaşar Kemal, who has a valuable place in contemporary Turkish literature with his universal works, the lives of people from different socio-economic environments are reflected in their sociological and psychological contexts. In the author's novels progressing in Çukurova, while human relations are handled with an ecological approach in line with the social transformations shaped by economic and political laws, masculinity status are also intensely encountered. The criticism of masculinity in this article is discussed through the work of Akçasazın A ğaları by Yaşar Kemal, one of the important names of contemporary Turkish literature. This work consists of two volumes called Demirciler Çarşısı Cinayeti and Yusufçuk Yusuf. The discussion throughout the text allows for a rethinking of the socioeconomic and political transformations in Turkey. It also reveals which masculinity norms these transformations produce. The important point here is that hegemonic masculinity exists within power relations and social institutions and political field. In this context, Akçasazın A ğalarl draws attention to different class and cultural relations, political atmosphere, and structures such as law that create hegemonic masculinity. In addition, the work provides a sociological analysis of male characters' power-building and their juxtaposition with power elements outside themselves based on a patriarchal mentality. In the novel, masculinity status is depicted as immanent with the transforming capitalist production relations.

In the work, Yaşar Kemal opens an important field of criticism in terms of gender, while analyzing the dimensions of spatial and social transformation in which masculinity maintains its strength through Derviş and Mustafa, feudal lords who have a feud. The author shows the dominant forms of masculinity as a form of power-building despite the often criticized sources of social inequality. Dominant masculinity traits oppress both weak and powerless men (internal hegemony) and women (external hegemony). Undoubtedly, it is seen that the social analysis of the novels reveals important data for the studies of masculinity. In rural social structure, masculinity status are mostly identified with landlord. There are features such as owning land, earning income from the land, employing many peasants, using violence, controlling income, and being involved in politics. These features are supported sociologically and anthropologically, considering the historical reality of hegemonic masculinity.

When the social structure that is the subject of Demirciler Çarşısı Cinayeti and Yusufçuk Yusuf novels is carefully analyzed, hegemonic masculinity is handled clearly through the characters (Derviş and Mustafa). For example, narcissism stands out as an important dimension of Derviş's gender identity. On the other hand, Derviş, who is firmly committed to Turkmen traditions and hospitality, ruthlessly maintains customs such as the blood feud led by men. Throughout the novel, blood feuds are frequently encountered in feudal conditions. Killing people is almost a tradition and this tradition is maintained by men. In this process, it is observed that the landlords, who are in the middle of the blood feud, maintain a relationship of dependency with their tribe members. The landlords have unconditional power over the peasants who face all kinds of humiliation. With the emergence of new landlords, the conflict of fertile lands increases, and the authority of some landlords is lost. The most important way out for these landlords is to contact the political authority. At the same time, this situation should be evaluated as a result of the former landlords' desire to maintain their masculine 
power in accordance with the changing conditions. Social inequality, violence and oppression affect the poor deeply. Gender inequality affects women. Gender inequality that arises through lawlessness is maintained through men in the economy as well. What is clear is the fact that men are great partners in the patriarchal system in the social division of labor and sharing.

The socio-political processes affected by the relations of production also bring about changes in space. With the settlement of the nomadic tribes in Çukurova in line with the demands of the political power, the occupations in tent life and animal husbandry shifted to the agricultural field and the doors of the village life were opened. In the social structures in which the landlords have power, stratification is much more intense. At the same time, patriarchy is maintained in a social structure that progresses through tribes and extended families. As former landlords Derviş and Mustafa who are the main characters of the novel, lose their status as they age. This situation contradicts with the traditional social structure. Their dominance over the means of production passes to their children. Thus, there is an important change of direction in the patriarchal order. With the progress in agricultural capitalism, the proliferation of factories, the change of economic power, and the modernization of production processes are undoubtedly reflected in the masculinity status of the younger generation. In this order, ownership and accumulation are still in men. All agricultural workers are poor. The pressure on women continues to increase.

In the final analysis, Yaşar Kemal's being a novelist of hope does not result in ignoring a social reality such as hegemonic masculinity. This reality is revealed in another network of inequality relations such as class, cultural and religious. This situation gives hegemonic masculinity a historical-social character. Based on the results of the study, it can be said that it is possible to consider important literary texts with high aesthetic value based on social historical facts in the context of masculinity studies.

\section{Giriş}

Sosyolojik ve antropolojik bir saha olarak toplumsal cinsiyet olgusunu, erkeklik vurgusu üzerinden değerlendiren çalışmaların, sosyal bilimler literatüründe son yıllarda ivme kazandığını söylemek mümkündür. Bu durum, kültürel antropolojide önemli yer tutan akrabalık sistemleri, mülkiyet, değiş-tokuş, ekonomik ve toplumsal iş bölümü gibi temel konularda erkeklik üzerinden tartışmaların yürütülebileceği gerçeğini güçlendirmektedir. Bu noktada feminist antropologların çabalarının, kadınların yoğunlukla toplumsal yaşamdaki rolüne, yani kamusal alandaki görünümüne yöneldiğinin altını çizmek gerekir (Martin, 2021; Bribiescas, 2021; Lax\&Mertig, 2020; Doorn\&March, 2020; Lindisfarne\&Cornwall, 2016). Daha genel çerçeveden bakıldığındaysa 1960-70'li yılları takip eden süreçte toplumsal cinsiyet merkezli sosyal bilim çalışmalarında, toplumsal cinsiyet eşitsizliğinin öznesi olan kadınların birçok başlıktaki sorunlarını içeren konuların yer aldığı görülür. Ne var ki, bu çalışmalarda erkeklik olgusuna tam anlamıyla önem arz edildiğini düşünmek zordur. Yeterli düzeyde olmamakla beraber toplumsal cinsiyet alanındaki çalışmalar, "kadınlık gibi erkekliğin de tarihsel, kültürel ve toplumsal koşullar tarafından şekillendirilen bir toplumsal cinsiyet kategorisi olduğunu 
ortaya koymuştur. Tarihsel, toplumsal ve kültürel koşulların bir ürünü olan ataerkil söylem, erkekler ve erkekliklerin inşa sürecini her alanda belirleyici bir nitelik taşımaktadır" (Arık, 2016: 232-233). Erkeklerin konumuna göre, “antropolojik olarak kadınların ikincilliğinin kökenleri hem tarihsel olarak hem de coğrafi olarak farklı sosyo-kültürel toplulukların siyasal örgütlenme biçimleri ve üretim ilişkileri arasındaki farklılıklar ile bu farklılıklara karşın, değişen derecelerde olmakla birlikte kadınların ikincil konumlarının evrensel olduğu iddiası" (Yanıkkaya Aydemir, 2012: 113) erkeklerin odakta olduğu tahakküm hiyerarşisinin varlığı gözetildiğinde çoğu zaman kendisini doğrulamaktadır. Bu tartışmalarda kadınların ezilmişliği nasıl yaşadıklarını anlamak kadar, erkeklerin eril iktidar konumlarını nasıl sürdürdüklerini ve baskı mekanizmalarını nasıl inşa ettiklerini çözümlemek de önemli olmalıdır (Sancar, 2013: 15). Sonuçta toplumsal cinsiyetin kurumsallaşmasında kadınlık ve erkeklik biçimleri, karşılıklı yeniden üretilen ilişkiler etrafında tek bir yapısal gerçekliğe, erkeklerin kadınlar üzerindeki küresel egemenliği üzerine oturtulur (Connell, 2016: 245). Bu yapısal olgu, aynı zamanda bir bütün olarak kültürel bağlamda da toplumsal hegemonik bir erkeklik biçimini tanımlayan erkekler arası ilişkilerin temel eksenini oluşturur. Hegemonik erkeklik, kadınlarla ilgili olduğu kadar, ikincil konuma itilmiş çeşitli erkeklik biçimleriyle bağlantılı biçimde de inşa edilmektedir. Erkeklerin kadınlar üzerindeki tahakkümünün kurumsallaşması "dışsal hegemonya", bir grup erkeğin diğer erkekler üzerindeki hâkimiyetiyse "içsel hegemonya" olarak ifade edilir (Türk, 2015). Böylece farklı erkeklik biçimleri arasındaki etkileşim, ataerkil toplumsal düzenin işleyiş biçiminin ayrılmaz bir parçasını teşkil eder hâle gelir (Connell, 2016: 267-268). Daha geniş bir perspektiften bakılırsa, cinsiyetçi toplumsal düzenin işleyişi çözümlendiğinde eril tahakküm dâhil olmak üzere toplumsal cinsiyete dair gerçekler coğrafyadan, kültürden, politik iklimden ve farklı iktidar araçlarından ayrı düşünülemez (Mutluer, 2013: 17).

Erkeklik çalışmaları arasında son yıllarda edebiyatın da önemli bir yer edindiğini söylemek mümkündür. Türk edebiyatındaki farklı edebi metin incelemelerinde erkeklik performansları derinlemesine analiz edilmektedir (Parın, 2019; Arslan, 2019; Gedik, 2016). Sosyoekonomik ve politik gerçekliğe dayalı edebi metinlerin, sosyolojik ve antropolojik bakımdan titizlikle kavranışı erkeklik olgusuna olan duyarlılığı artırmaktadır. Başka bir ifadeyle erkeklik, edebi metinlerin sosyolojik ve antropolojik çözümlemesinde önemli bir kesişim noktasıdır. Bu açıdan Utanır Karaduman’ın şu sözleri oldukça dikkat çekicidir:

\footnotetext{
"Erkeklik imgelerini incelemek amacıyla erkek dünyasının anlatılmayan ve çok fazla dillendirilmeyen bir dünya olduğu düşünüldüğünde edebiyat türleri içinde özellikle romanlar önemli kaynaklar arasında yer alır. Erkeklerin 'erkek' olma, olabilme kaygısıyla yaşamlarındaki çelişkiyi gizlemeleri ve dillendirilmeyen bir dünya yaratmaları, kazanılan erkeklik durumunun kaybedilebilecek kaygan bir zeminde yer almasından kaynaklanmaktadır. Bu kaygıyla kişisel duygular, çoğu erkek tarafından gizlenebilmektedir. İşte bu açıdan romanlar, erkeklerin dünyasının kapılarını açması bakımından erkeklik incelemelerine elverişli olanaklar sunar" (Utanır Karaduman, 2020: 528).
}

Türk edebiyatındaki erkek temsillerinin, erkeklik üzerinden baskın karakterlerle yer edinişi her ne kadar sonrasında kesintiye uğrasa da temelde 2000'li yıllar itibariyledir. Bu yıllardaki öykü ve roman türlerinde "delikanlı”, "bıçkın”, “atarlı” erkek imgesiyle karşıla- 
Şılmaktadır. Öne çıkan isimlerse yeraltı edebiyatının temsilcisi olarak görülen Emrah Serbes, Hakan Günday, Alper Canıgüz, Murat Menteş gibi yazarlardır. Bu yazarlar aracılığıyla erkeklik performansları şiddet, iktidar, hedonizm gibi başlıklarla yakınlaştırılmaktadır. $\mathrm{Bu}$, Türk edebiyatında erkeklik temsillerindeki önemli bir dönüşüme işaret eder. Nihayetinde edebi metinlerdeki erkeklik performansları, erkeklik norm ve pratiklerinin yeniden üretiminde önemli araçlardan biri hâline gelebilmektedir. Elbette ki, tersine edebiyat, bu norm ve pratiklerin yıkımı için bile işlev üstlenebilmektedir. İkisinden hangisinin Türk edebiyatında önem kazandığının tespitiyse uzun bir tarihsel şemada dönemleştirmelere sadık kalınarak yapılacak erkeklik sorgulamalarıyla mümkündür ki, böylesi bir çaba, metodolojik olarak geniş bir çalışmayı gerekli kılar.

$\mathrm{Bu}$ çalışmada erkeklik eleştirisi, çağdaş Türk edebiyatının önemli isimlerinden Yaşar Kemal ve onun Akçasazın Ağaları (Demirciler Çarşısı Cinayeti ve Yusufçuk Yusuf) yapıtı üzerinden tartışmaya açılmaktadır. Bu tartışma, eserde cisimleşen Türkiye'deki sosyo-ekonomik ve politik dönüşümlerin yeniden düşünülmesine olanak sağladığ1 gibi, bu dönüşümlerin hangi erkeklik normlarını ürettiğini veya hangi normlarla etkileşime girdiğini ortaya koymaktadır. Sosyolojik ve sosyal antropolojik düşünüşle yapıttaki erkek kahramanların eril tahakküm yaratma süreçleri ve erkeklik hâlleri ilk kez R. W. Connell (2016) tarafindan kavramsallaştırılan "hegemonik erkeklik" üzerinden ele alınmaktadır.

Hegemonik erkekliğe geçmeden önce, eril tahakküm kavramının neye işaret ettiğini vurgulamak gerekir. Pierre Bourdieu'dan (2014: 86) hareketle sayısız tekil tahakküm ilişkisinin nihai ilkesi olan eril tahakküm, kadınların varlığının, “algılanan-varlık” olarak sembolik nesneler hâlinde oluşturulmasıdır. Bunun anlamı, kadınların bedensel bir güvensizliğe hapsedilerek sembolik bağımlılığın sınırlarında tutulmasıdır. Toplumsal düzen, eril tahakkümü sürekli üretime tabi tutan kocaman bir sembolik makine gibidir. Bu makinede kadınlar, başkalarının bakış açıları tarafından var edilmektedir. O bakış açıları da toplumsal ve kültürel normlar dâhilinde ataerkil düzende inşa edilen bakış açılarıdır. Örneğin, "güler yüzlü”, "sempatik,", "itaatkar”, "ölçülü”, "ağırbaşlı” gibi kadınların nesneleştirildiği söylemlerden söz edilebilir. Akçasazın A ğaları eserinde bu anlamda Çukurova Bölgesi’nde kadınların hangi normlara sokulduğuna dair göstergelere rastlamak mümkündür. Hegemonik erkeklik ise belirli erkek gruplarının iktidar ve zenginliği ellerinde nasıl tuttuklarını, eril tahakkümü yaratan toplumsal ilişkileri nasıl meşrulaştırdıklarını ve yeniden ürettiklerini ortaya koymaktadır (Carrigan et al., 1985). Connell'e göre (2016: 249) kavram; erkeklerin hâkimiyetini, kadınlarınsa bağlılığını garanti altına alan ataerkilliğin meşruiyet problemine cevap veren bir toplumsal cinsiyet pratiğidir. Bu pratik, Connell açısından (2016: 243); her ne kadar farklı coğrafya, kültür ve tarihlere göre değişkenlik gösterse dahi evrensel niteliğinden ödün verilmeden ataerkil düzeni yasalaştıran erkek kimliğinin idealleştirilmiş biçimini temsil eder. Dolayısıyla hegemonik erkeklik, belirli erkeklik pratiklerinin idealleştirilmesine dayanmaktadır. Buradaki önemli nokta, hegemonik erkekliğin güç ilişkileri içerisinde, toplumsal kurumlar ve politik alan dâhilinde vücut bulmasıdır. O nedenle bu idealleştirilen pratikler genel bir erkek cinsiyet rolü, bir kişilik özelliği veya karakteri değildir. Nihayetinde, Connell'in Antonio Gramsci'den emanet alarak erkeklik kavramına eklemlediği hegemonya, "acımasız iktidar 
çekişmelerinin ötesine geçerek özel yaşamın ve kültürel süreçlerin örgütlenmesine sızan bir toplumsal güçler oyununda kazanılan toplumsal üstünlük”tür (Connell, 2016: 269). Akçasazın A ğaları eseri de, bu bağlamda hegemonik erkekliği hayata geçiren farklı sınıfsal ve kültürel ilişkilere, politik iklim, sosyal etkileşim, hukuk gibi yapılara dikkat çekerek bunları güç ilişkileri dâhilinde ele alma olanağı sunar.

\section{Akçasazın Ăgaları'nda (Demirciler Çarşısı Cinayeti ve Yusufçuk Yusuf) toplumsal dönüşüm ve erkeklik hâlleri}

Çağdaş Türk edebiyatında evrensel düzeydeki eserleriyle değerli bir yeri olan Yaşar Kemal'in romanlarında, farklı sosyo-ekonomik çevrelerden insanların yaşamları, sosyolojik ve psikolojik bağlamları içerisinde yansıtılır. Yazarın Çukurova' da geçen romanlarında, ekonomik ve politik yasaların biçimlendirdiği toplumsal dönüşümler doğrultusunda insan ilişkileri, ekolojik bir yaklaşım eşliğinde işlenirken erkeklik hâlleri de yoğun olarak karşımıza çıkar. İki ciltten oluşan Akçasazın Ağaları eseri, erkek karakterlerin iktidar kurma ve kendi dışındaki iktidar unsurlarıyla ataerkil bir zihniyet temelinde yan yana gelme durumlarına dair bir içerik okuması sağlar. Romanda erkeklik hâlleri, dönüşen kapitalist üretim ilişkileriyle içkin bir hâlde betimlenmekle birlikte ataerkil bir atmosferde "endüstriyel kapitalizme geçiş, sosyal sınıflar arasındaki uçurumu derinleştirirken insan toprak ilişkisinin değişimi, sömürünün niteliği, yoksulluk, sosyal dışlanma, mülksüzleşme âdeta yaşanan toplumsal gerçekliğin adı olur" (Şeker\&Özcan, 2021: 90). Öte yandan Yaşar Kemal, erkeklerin belirlediği bir dünyada bir şeye de başarıyla dikkat çeker. İmtiyaz ve zenginliğin sağlandı̆̆ı maddi koşullardan daha temel maddi koşullara dayanan farklı bir kültürel oluşumu ön plana çıkarır ve kültürel dokuyu ne pahasına olursa olsun halk gelenekleriyle harmanlayarak roman kurgusunda işler (Tharaud, 2017: 44). Böylece inşa edilmiş iktidar araçlarıyla bütünleşen erkeklik hâllerinin dışındaki insancıl kültürel doku da kendisini hissettirir.

Akçasazın A ğaları'nın ilk cildi Demirciler Çarşısı Cinayeti (1998); “o iyi insanlar, o güzel atlara bindiler çekip gittiler" cümlesiyle başlayıp yine aynı cümleyle sonlanır. Yazar, romanın ikinci cildi Yusufçuk Yusuf'a (1999) ise bir kelimesi eksik olarak "o iyi insanlar, o güzel atlara bindiler gittiler" cümlesiyle başlarken, romanın sonunu "o iyi atlar, o iyi insanları aldılar çektiler gittiler” cümlesiyle getirir. Bu ifadelerin, her iki roman söz konusu olduğunda arka planında anlamlı sosyolojik verilerle desteklendiğini ve bunların değişim, yozlaşma, ekolojik yıkım, ekonomik ilerleme ekseninde çözümlenmesi gereken birçok sürece gönderme yaptığını belirtmek gerekir. Romanda Sarılar Aşireti'nden Sarıŏlu Derviş Bey ile Akyollu Aşireti'nden Mustafa Bey, bakmakla yükümlü oldukları aşiret insanlarıyla beraber kendi sosyal ortamlarında yaşarlar. Bu can düşmanları arasındaki kan gütme süreci, dönüşen sosyo-ekonomik koşullara uygun biçimde noktalanır. Feodal beylerin ölümüyle geride kalan ailelerin üyeleri Adana’ya yerleşmiş, yeni sermaye sınıfının içinde yerlerini özenle almışlardır. Kan davasını sürdüren roman karakterleri açısından ilginç olan şey, iki ağanın da İstanbul'da eğitim görmüş olmalarıdır. Cumhuriyetin ilk dönemine denk gelen bu süreçte örneğin Derviş Bey’in Batı dillerinden birkaçını bilmesi, üniversite okumuş olması, aynı şekilde Mustafa Bey'in de İstanbul'da eğitim görmüş olması toplumsal cinsiyet rollerine ilişkin ataerkil davranışlarında bir değişim meydana 
getirmemiştir. Her iki bey, kendi ataerkil gerçekliklerini var ettikleri toplumsal koşullarda katı cinsiyetçi tutumlarından bir şey kaybetmemiştir. Bu pencereden bakıldığında Yaşar Kemal, romanında erkeklik hâllerinin gücünü koruduğu mekânsal ve toplumsal dönüşümün boyutlarını en ince ayrıntısına kadar verirken, toplumsal cinsiyet açısından önemli bir eleştiri alanı açmaktadır. Yazar, yer yer eleştirilen toplumsal eşitsizlik kaynaklarına rağmen bir iktidar unsuru olarak erkekliğin baskın biçimlerini gösterir. Parayı kullanan başat erkeklik özellikleri hem zayıf ve güçsüz erkekleri (içsel hegemonya) hem de kadınları (dışsal hegemonya) ezmektedir. Hiç şüphesiz ki, bu anlamda söz konusu yapıtların sosyal analizinin erkeklik çalışmaları için önemli veriler ortaya çıkarması mümkündür.

Kırsal toplumsal yapıda erkeklik hâlleri çoğunlukla bey ya da ağalık tipleriyle özdeşleştirilmektedir. Toprak sahibi olmak, topraktan gelir elde etmek, kadın veya erkek fark etmeksizin çok sayıda köylü çalıştırmak, şiddet uygulamak, geliri kontrol etmek, ata veya otomobile binmek ve bunlar gibi çok sayıda metaya sahip olmak, siyasetle ilgilenmek gibi ataerkilliğin erkeklerin lehine olan tüm süreçlerinden payına düşeni almak ve bunu tavizsizce sürdürmek gibi genel nitelikler söz konusudur. Bunlar, hegemonik erkeklik olgusunun tarihsel gerçekliği gözetildiğinde sosyolojik ve antropolojik açıdan desteklenmektedir. Bu anlamda yakın bir geçmişte de olsa Kıray’ın toprak ağalarıyla ilgili ileri sürdügü şu kavramsal çerçeve, Yaşar Kemal'in romanlarını sosyolojik anlamda çözümlemek için kullanılabilir:

“Toprak ağaları mutlak bir iktidara sahiptir; yalnızca yanlarında çalıştıkları üzerinde değil, köylünün de geçim olanaklarını kontrolleri altında tutmakla kalmıyor, yine feodal toplumsal tabakalaşma sistemini çağrıştıracak şekilde, köylünün yaşamının her yönüne müdahale ederler” (Kıray, 1999a: 11).

Diğer yandan Yaşar Kemal, bu baskın ağa/bey karakteriyle özdeş ataerkil ögeler ile ekonomik ve politik gücü elinde bulundurarak erkeklik hâllerini sürdüren karakterler dışında iyi ve adil olduğu için sırtından vurulan demirci Mustafa, kendisine yapılan haksızlığa karşı Kurtboğa Ağa'yı öldüren Tellal, köylülere haksızlık yapan Süleyman Aslansoypençe'yi vuran Mestan ve ağaların zulmüne uğrayan Arzuhâlci Ali gibi sosyal karakterleri de işler. Yazar, güçsüz ama onurlu ve hakikati bilen bu insanlar tarafından öldürülen hırs abidesi ağaları okurun dikkatine yenilmiş olarak sunmaktan geri durmaz. Ataerkil yapının elini güçlü kıldığ1 ayrıcalıklı ağa/bey rolündeki erkeklerin bir kısmı yazarın biçimlendirdiği roman evreninde açıkçası yok edilirler. Derviş ve Mustafa gibi toplumsal konumları değişime yenik düşenlerse kendi sonlarını beraberinde getirirler.

\section{Kültürel bir olgu olarak hegemonik erkeklik üzerine sosyolojik bir analiz}

Demirciler Çarşısı Cinayeti ve Yusufçuk Yusuf romanlarına konu olan toplumsal düzen dikkatlice analiz edildiğinde, hegemonik erkekliğin karakterler üzerinden net bir biçimde işlendiği görülebilmektedir. Bunlardan Derviş Bey, "yaşı elliye yakın, saçları apak ama, o daha sırrım gibi, dimdik. Ve yirmi yaşında bir delikanlı çevikliğiyle ata biner, Arap atının üstünde gözleri ileride, göğsü dışarda sol kamçılı eli baldırının üstünde görkemli otururdu" (Kemal, 1998: 15). Gece uyurken bile tabancısını yanında taşır: "Derviş Bey kendi yüzünü 
dehşet severdi. O da kendi yüzüne bakmaya doyamazdı. Aynaya bakar bakar, yüzü aynada değişir, güler, ağlar, acı çeker, sevinir, taş gibi donar, sonra sapsarı kesilir: 'Ölüm' der, aynayı elinden firlatırdı” (Kemal, 1998: 15). Karakterine bir bütün olarak bakıldığında narsisizmin Derviş Bey’in toplumsal cinsiyet kimliğinin önemli bir boyutu olduğu görülür. Romanda Çukurova coğrafyası, güçlülerin her anlamda hükmünü sürdürdükleri topraklardır. Derviş Bey dönem olarak bu topraklarda yetişmiş ve "bir ömür boyu gerilmiş, kudurmuş, al kan içinde, ölmekle öldürmekten başka bir şey düşünmemiş, kaçmış, saklanmış, öldürmeyi, ölüm korkusunu ömrünün her saniyesinde yaşamış. Ve bütün bedeni korkudan korkuya kesmiş bir adam"dır (Kemal, 1998: 23). Öte yandan Türkmen geleneklerine, bu gelenekle anılan konukseverliğe sıkı sıkıya bağlı Derviş Bey, erkeklerin yönlendirdiği kan davası gibi töreleri acımasızca sürdürmektedir. İşkencenin her türünü uygulamaktan zevk alan sadist bir kişilik yapısına sahiptir. Derviş Bey, kan davalısı Mustafa Bey’in ailesinden birilerini öldürmesi için daha çok yetiştirdiği yanaşmalarını kullanır. Bunlardan biri de Mahmut’tur. Adam öldürmek için adam yetiştiren bu tipler yerine göre oldukça zalimdirler. Örneğin, "Mahmut için adam öldürmek bir şey değildi ki. Bu kapıda salt adam öldürmek için duruyordu. Bey bunun için besliyordu onu. Onu da ötekileri de...” (Kemal, 1998: 53). Mahmut, Derviş Bey’in kardeşi Cevdet Bey’e karşılık Akyollu Murtaza Bey’i öldürür. Cinayetten sonra dağlara gizlenen Mahmut, kasaba ağalarının etkisiyle yakalandıktan sonra Derviş Bey’in yönlendirmesiyle cinayet işlediğini söylemez. Ne var ki, karakolda gördüğü işkenceden sonra ölür. Kasabanın ataerkil zihniyetini sürdüren ileri gelenlerinin satın aldıkları doktor, Mahmut için karakola getirilirken yolda kalp yetmezliğinden öldüğü şeklinde rapor yazar. Daha sonra, "Mahmut’un tanınmayacak kadar paramparça olmuş kanlı ölüsü iki buçuk gün” kasaba alanında halka ibret alsınlar diye gösterilir (Kemal, 1998: 477).

Kan davasının bir sırası vardır. Sarığlu Derviş Bey, sıranın kendisinde olduğu bilinciyle ölüm ve korku duygularına saplanır. Bazen hedefe asıl kişiler yerine yanaşmalar girer. Bu ise öç almanın bir başka boyutudur. Derviş Bey’in acımasızlığı, kasabada yeni ağaların kışkırtmasıyla özellikle Derviş’e yakınlaşmanın yollarını bulan Kabakçızade Mahir Bey’in tuttuğu Ahmet aracılığıyla İstanbul'da okuyan kızı Nurhan için etrafa yazılan cinsiyetçi cümlelere ilişkin ortaya çıkar. Ataerkil sistemde erkekler arası hesaplaşmanın en kolay yolu kadınlardan geçmektedir. Derviş gibi feodal bir ağanın bundan etkilenmemesi mümkün değildi. Kasaba duvarlarına yazılan; "Derviş Bey dedikleri... Burada Beylik, Ağalık satar, kızı İstanbul'da fink atar. Kızları İstanbul'da randevu evlerinde çalışır, burada onların ve bütün kasabanın boynuzu göklere kadar uzar" (Kemal, 1999: 217) biçimindeki sözler bunlardan sadece birkaçıdır. Buna benzer cümleler kasabadaki duvarlara karalanmıştır. Bunun bedelini ödeyen Nurhan olur. Eğitimi yarıda kesilir ve her şeyden habersiz eve çağrılır. Hegemonik erkeklik düsturuyla Derviş Bey'in namusunun lekelenmesine neden olduğu ileri sürülen Nurhan, babası tarafından adeta lanetlenir. Fakat ileride Derviş Bey kızını anlasa da yüzüne bakamaz. Sonuçta bu durum, yeni ölümler getirir. Derviş Bey, "ama ben bunları affedemem. Namusumla oynadılar. Hükümet cezalarını versin. İsterse hiç vermesin. Ben onlara cezalarını kendi elimle vereceğim” diyerek başka cinayetlerin kapsını aralar (Kemal, 1999: 223). Bir gün kasaba kalabalığında bu konu üzerine Mahir Bey tarafından planlandığı şekilde, Derviş Bey’le 
dalga geçmesi istenen Deli Hacı, yüzüne karşı insanlar içinde "boynuzları göğe, yıldızlara erişmiş bir pezevenk" (Kemal, 1999: 238) dediği Derviş Bey’in büyüttüğü Mahmut'un oğlu Yusuf tarafindan öldürülür.

Sosyolojik açıdan bakıldığında "ataerkil toplumca biçimlendirilmiş erkek, varoluşu gereği sürekli ve daha çok erk ister. Bununla birlikte toplum da genel inanç ve değerler çerçevesinde biçimlendirdiği rol kalıplarının hem kadınlar hem de erkekler tarafından eksiksiz yerine getirilmesini bekler" (Çelik, 2016: 2). Üniversiteden acele bir şekilde getirilip eve hapsedilen Nurhan'da somut olarak görüldügü gibi, "kadınlar, yüzyıllar boyunca erkeklerle aralarındaki temeli eşitsizliğe dayanan ilişkileri sebebiyle erkek egemen bir dünyada kuralları erkekler tarafından belirlenmiş bir hayatı yaşamak zorunda kalmışlardır” (Soysal Eşitti, 2020: 117). Romandan anımsanacak olursa, Derviş Bey feodal bir gururla kızını çağırıp sorgular. İnanmakla inanmamak arasında kalsa dahi yazıları yazanı bulup öldürmek ister. Nitekim bu tutum, dönemin toplumsal yapısında “erkek şerefinin kadınların davranışlarına yakından bağlı olduğu" toplumsal cinsiyet hiyerarşisinin ürettiği sorunsalı örnekler (Kandiyoti, 2015: 196).

Derviş Bey, hegemonik erkeklik öznesi olarak diğer erkekleri de kullanır. Cinayet işlettiği Küçük Yusuf'u ele geçmesin diye kendisi öldürmeyi tercih eder. Fakat bu esnada kasaba ağaları Yusuf'u ele geçirip cinayeti Derviş Bey’in isteğiyle işlediğini söyletmeyi planlarlar. Muzaffer ise babası Derviş'in böyle bir şeyle suçlanması neticesinde asılacağını söyler. Babasını ikna etmek amacıyla; "kasabadaki düşmanlar da bunu bildikleri için aralarında para toplamışlar, ne kadar olduğu belli değil, Candarma Yüzbaşısının emrine vermişler, o da... Bulmalıyız baba, bulmalıyız Yusuf'u ve öldürmeliyiz. Yoksa baba, o yaşadıkça senin her zaman boynun ipte demektir..." diyerek babasından kaynaklı yaşayacağı sıkıntılarla yüzleşmek istemez (Kemal, 1999: 544). Muzaffer'in ileride Mustafa Bey'in oğlu Memet Ali ile iş ortaklıkları kuracağı ve son hızla topraktan sanayiye kayacakları düşünüldüğünde, tepkisini yeni hegemonik tipler ya da "yeni ataerkil ağalar" üzerinden değerlendirmek gerekir. Muzaffer'in içinde bulunduğu ruh hâliyle çoktan yeni kötü olanın karanlık yüzünü içselleştirdiği ortadadır.

Roman boyunca feodal koşullarda kan gütme olaylarına sıklıkla rastlanır. İnsan öldürmenin kör bir gelenek hâline geldiği ve bunun erkekler eliyle inatla sürdürüldügü yörede aleni bir tutumdur. Bu süreçte kan gütme olayının ortasında olan beylerin, aşiret üyeleriyle bağımlılık ilişkisi sürdürdükleri de gözlenir. Beylerin her türlü aşağılanmayla karşı karşıya bıraktıkları köylüler, yanaşmalar, yarıcılar, ortakçılar gibi çiftlik halkı üzerinde koşulsuz iktidarları vardır. Ayrıca yaşadıkları çiftlik konaklarının görkemi, beylerin gücünü simgeler. Bununla yan yana yürüyen bir hegemonik erkeklik, "sadece erkeklerin kadınlar üzerinde kurduğu üstünlüğe değil, erkeklerin diğer erkekler üzerinde kurduğu üstünlüğe ve iktidara da karş1lık gelir. Diğer erkeklerin eleştirilmesi ve hor görülmesi üzerinden konumunu inşa eden hegemonik erkeklik, yok sayma ve üstünlük gibi mekanizmaları kullanır" (Soysal Eşitti, 2020: 122). Örneğin, romanda yerel otoritelerin her türlü olanağını kullanmak için yollar aranır. Kan davası ekseninde işlenen cinayetlerden sonra devletin görevlileri bir şekilde etki altında tutulur. Yeni ağaların türemesiyle bereketli toprakların kavgası çoğalınca beylerin bir ceza unsuru olarak ağırlıkları kaybolurken, merkezi iktidarın yereldeki kurumlarının temsil- 
cilerinden bu davranışların cezalandırılması için baskılar artar. Kuşkusuz bunu yeni ağaların değişen koşullara uygun olarak erkeklik iktidarlarını eski olanı tasfiye ederek sürdürmek istemelerinin bir sonucu olarak değerlendirmek gerekir.

Hegemonik erkeklik hâllerinde eğitimin etkisinin olmadığı ortadadır. Derviş ve Mustafa, kan davalı iki beydir. Öyle ki, birbirlerinden övünecek kadar birbirlerine saygı da duymaktaydılar. Çukurova'da son günlerini yaşayan iki aşiretin beyleri yukarıda da bahsedildiği üzere iyi eğitim almışlardır. Birinci Dünya Savaşı öncesi Derviş Bey, İstanbul Darülfünunu’nun hukuk kısmında okurken, Mustafa Bey Sultaniyi bitirmiştir. Okuduğu yıllarda cömertliğiyle tanınan Derviş Bey; Fransızca, İngilizce, Rumca ve Arapça öğrenmiştir. Çanakkale'de savaşan, Toroslar'da Fransızlara karşı çete kuran İstiklal madalyalı Derviş Bey'in kan gütme olayındaki işlevi okura ilginç gelebilir. Örneğin, Derviş Bey’in cinsel saplantıları olan kız kardeşi Sabahat Hatun'un eşi Kamil'i kırbaçlayarak, atını üzerine sürerek, yetmedi adamlarına kırbaçlatarak öldürmesi feodal toplumda ceza kesen bey imajında somutlaşır. Ona göre nedeni, eniştesinin eşine sahip çıkmamasıdır. Soyunun namusunu beş paralık etmesidir. Parçalanmış ölü beden karşısında Derviş Bey şunu söyler: "Götürün şunu da şöyle çiftliğin dışına, köpeklere atın” (Kemal, 1998: 140). Derviş Bey’e göre, karısına sahip çıkamayan bir erkek ölümü hak etmiştir. Bu olaya ilişkin görüldüğü gibi hegemonik erkeklikte erkekliğin kendini üretmesi ve sürdürmesi yalnızca kadınların ikinci plana atılmasıyla ilgili değildir. Kendisinin dışında kalan diğer erkek(lik)ler de -bir dereceye kadar karşıtlık oluşturmasına izin verilse de- ikincilleştirilmektedir. Bu da erkekliğin net bir tanımı olamayacağını, bilakis küçük bir grup erkeğin ellerinde tuttukları gücü, birbirlerine içkin olan ırk, sınıf ve cinsiyet eşitsizliklerini pekiştirerek kadınlara ve diğer erkeklere karşı kullandığını göstermektedir (Kepekçi, 2012: 82). Başka bir açıdan, “erkeklik şiddetine en çok maruz kalanlar ise büyük ölçüde erkeklerdir. Hegemonik erkeklik, hep tekrarlanan ve sistem tarafından sürekli onaylanan bir yapıdır. Sürdürülebilir olabilmesi, bu erkeklik biçimiyle özdeşleşen davranış kalıpları ve ritüelleri yaygınlaştırması gerekir” (Sezer Şanlı, 2019: 294).

Kadın bedeni, ataerkil toplumları biçimlendiren erkek egemen değerler açısından bir mücadele alanıdır. Sabahat Hatun üzerinden eşi Kamil'in öldürülmesi, Derviş Bey'in üniversite okuyan kızı hedefte tutularak namusa vurgu yapılıp babanın toplumsal konumuna dokunulması bir yaptırımlar dizisini ortaya çıkarmıştır. Toplumsal korumasını gerçekleştiremediği namus temelinde kadını ve onu koruyamayanı cezalandırmak, feodal sosyal ilişki ağlarında rastlanan bir sorundur. Erkek iktidarı ya da hegemonik erkeklik bu şekilde doğallaştırılmakta veya normalleştirilebilmektedir.

Romana dönülecek olursa, Akyollu Mustafa adamlarıyla, Derviş Bey’e pusu kurar. Yanlışlıkla başkalarını (Antepli kaçakçıları) öldürüp mallarını adamları arasında pay ederken, onları Akçasaz bataklığına gömerler. Çevrede bilinmesine rağmen "hukuk" işlemez. Köylüler yoksuldur. Aileleriyle birlikte ağaların yanında iş tutarlar. Gelecekleri yok gibidir. Kolaylıkla eşkıya baskınlarına uğrayabilmekte, kızları dağa kaldırılabilmektedir. Eşkıyalar, Akyollu Mustafa Bey gibi, göçmen köylülerinin topraklarını köylerini yakarak ellerinden alacak kadar zalim davranabilmektedirler. Toplumsal eşitsizlik, şiddet ve baskı yoksulları derinden etkilemektedir. Toplumsal cinsiyet eşitsizliği ise daha ziyade kadınları etkisi altına almakta- 
dır. Hukuksuzlukla beslenen toplumsal cinsiyet eşitsizliğinin ekonomide erkekler aracılığıyla sürdürülmesinin işareti olan şu cümlelere dikkat çekmek gerekir:

"Köylüler Akçasazdan tarla kazandılar, ama kazandıkları tarlalar ellerinde kalmadı, çeltikçi yeni yetme ağalara kaptırdılar. Akçasaz bir dönüm toprağı olmayan nice adamları büyük çiftlik sahibi etti, zengin, milyoner etti. Fabrika sahibi etti. Akçasazdan yetişen ağalar politikaya atılıp bir süre koca bir memleketin kaderine hükmedenlerin arasına katılıp en olumsuz, en korkunç rolleri oynadılar" (Kemal, 1998: 123).

Bütün bu ilişkilerde iktidar sahibi erkeklerdir ve bu korkunç roller hep kadınlar üzerindeki baskıyla işlemektedir. Kadınlar üzerindeki tahakküm, bu rolleri kuran şeydir. Derviş Bey ile Mustafa Bey'in yanı sıra yeni ağaların toplumsal yaşamdaki ilişkileri irdelendiğinde egemenliğin kuruluşundaki güçlü ataerkillik hemen göze çarpar. Gerçek şudur ki, "hegemonik erkekliğin kamusal yüzünün, ille de iktidar sahibi erkeklerin ne olduğuna değil, ama bu erkeklerin sahip olduğu iktidarı ayakta tutanın ne olduğuna ve bu kadar çok sayıda erkeğin neyi desteklemeye yönlendirildiğine dair olması gerekir" (Connell, 2016: 270). Açık olan şey, toplumsal iş bölümü ve paylaşımda erkeklerin ataerkil sistemin büyük ortakları olduğu gerçeğidir.

Derviş ile Mustafa Bey arasında süren kan davası, romanda değişen sosyal ilişkilerle verilir. Yeni ağa tiplerinin ortaya çıkış koşullarına dikkat çekilir. Örneğin, on beş yaşlarında Darende'den gelen Memet Rüstemoğlu, bir ağanın yanaşmalığıyla hayata başlar. Köylerde çerçilik yapar, kasabada dükkân açar. Mal biriktirir. Sermayenin temeli olarak toprağı görür. Toprağın ölümsüzlüğü onu cezbeder. Derviş Bey’in zamanının geçeceğini bildiğinden onun topraklarını almaya niyetlenir. Çukurova'da çok kutsal olan topraktan sahiplenir. Derviş Bey ise yeni ağalara benzemeyi aşağılık bulur. Yeni ağaların varlıkları; usulsüz elde ettikleri topraklardan, eski ağaların varlıklarının bir kısmından, giden Ermenilerin geride bıraktıkları üzerinden bina edilir. Bunun yanı sıra tapucu Abdülhalik Efendi de ağalara, usulüne uydurup hazine mallarını verir. Hacı Osman Ağa, Süleyman Sami, Mahir Kabakçıoğlu, Hacı Kurtboğa, Süleyman Aslansoypençe, Cafer Özpolat, Muallim Rüstem Bey, Ala Temir Yamakl1, Zalımoğlu hepsi de yeri geldiğinde şeytana pabucunu ters giydiren, ekonomi-politiğin yeni aktörleri, daha doğrusu kurnazlarıdırlar. Bu dönemde Halk Partisi siyaseten güçsüzleşirken, iktidarın temsilcisi Demokrat Parti olur. Demokrat Partiye hızla entegre olan ağalar, yalnızca bir gecede gömlek değiştirirler. Demokrat Partiyle birlikte bu kez kredi muslukları Çukurova'nın yeni ağalarına açılır. Yaşar Kemal, söz konusu politik dönüşümü tarihsel koşulların toplumsal yönleriyle işler. Türkiye siyasetinde önemli kırılmaları taşıyan Halk Parti Dönemi’nin olduğu kadar, Demokrat Parti Dönemi’nin de Çukurova'daki etkilerine eleştirel bir mesafeden yaklaşır. Bunu yaparken roman kahramanlarından Mustafa Bey'in Demokrat Partiye, Derviş Bey'inse Halk Partiye yakın olduğunu hissettirmeyi ihmal etmez. Bu arada Mahir Bey, Demokrat Partiye tamamen sırtını yaslar. Roman dinamiğinden hareketle ele alındığında Sancar'ın şu ifadesine bakmak gerekir: "Erkek egemen toplumlarda farklı erkeklikler arasında hiyerarşi ve iktidar mücadelelerine dikkat çekilmektedir; devlet, ordu, iş gücü piyasası gibi kurumlaşmış patriarki alanlarındaki yapılanmış erkek egemenliğine özel vurgu yapılarak doğrudan siyasal ilişkilerine gönderme yapılmaktadır” (Sancar, 2013: 17). 
İnsanların değer yargıları, servet edinme dışında bir gerçekliği olmayan ekonomi-politik sürecin sonunda tüm özellikleriyle hegemonik erkeklik tiplerinde somutlaşır. Ağaların bir kısmı dönemin koşullarına göre çok iyi eğitim almışlardır. Örneğin, Mahir Bey Avrupa'da okumuştur. Ne var ki, tapu memuru Abdulhalik Efendi'ye yanaşmak onun için daha önemlidir. Kimsenin haberi olmadan satılığa çıkarılan hazine mallarından o da payını alır. Zamanla "nüfuzu, bol parası, dostları, arkasında dă̆ gibi partisi, bankalarda da istediği kadar kredisi” oluşmuştur (Kemal, 1999: 53). Sıra, Derviş Bey’in topraklarını elde etmeye gelir. Derviş Bey'in oğlu Muzaffer'i kazanarak babasını ikna etmenin yollarına bakmıştır. Onunla barışmak uğruna önerilen rezillikleri bile kabul etmiştir. Derviş Bey’in Tarsus Amerikan Kolejinde okuyan diğer oğlu Ceyhun ise ekonomik değişimi görürken babasını uyarır: "Dünya artık öküzün boynunda değil, peygamberin kelamında değil, Allah'ın ayetinde değil. Oğuzun geleneğinde değil, ekonominin sırtında duruyor" (Kemal, 1999: 67). Denebilir ki yazarın, "bu romanlarda yiten göçebelik değerlerini, bu değerlerin yaşatıldığ 1 toplumu ve bu toplumun insanlarını mutlak iyiler olarak anlatması, bu değerlerin yok olmasına yol açan kapitalist toplum değerlerini yermesi, ilk bakışta göze çarpmayan, ancak yazarın diğer yapıtlarındaki ortak özelliklerin anlaşılmasıyla belirginleşen” bir özelliktir (Aksu, 2003: 140).

Romanda, ekonomik dönüşüm ve erkekler aynı sahnededir. Para, erkeğin kontrolündedir. Olaylar, anlamlar, semboller, ilişkiler üzerine toplumsal süreci inşa edenler, değişen erkeklik hâlleridir. Ağalar, her dönemin iktidarının nimetlerinden yararlanmasını iyi bilmektedirler. Derebeyi olarak niteledikleri Derviş Bey gibi tipler, tek pati dönemiyle ya da İsmet Paşa'yla bir görülmektedir. Kasaba savcısına bazı tipleri sürmeleri için rüşvet verirler. Gücü yettikleri güçsüzlere, kasabanın ortasında şiddet uygularlar. Ağaların içinde olduğu şiddet olayları açısından bakıldığında, "hegemonik erkeklik pratiklerinden olan şiddet, aynı zamanda erkekliği yeniden üreten bir sosyal performanstır. Erkeklik ideolojisinin zayıflayacağından ya da hegemonik olma özelliğini kaybedeceğinden duyulan korku şiddeti araçsallaştırmaktadır" (Laloğlu, 2018: 393). Örneğin, kasabada dürüst bir insan olarak tanınan, ağaları eleştiren demirci Mustafa'yı dükkânında Kurtboğa'ya arkasından kurşunlatırlar. Arzuhâlci Ali’yi ortadan kaldırmayı denerler. Akçasaz bataklığını kurutup toprak edinmek isteyen köylüleri kurşunlatıp evlerini yakarlar. Bu esnada Mestan'ın silahından çıkan kurşunlar Süleyman Aslansoypençe'nin ölümüne neden olur. Kuşkusuz bu ölümden, ağaların deyimiyle toprakları elde etmeye çalışan "komünistler" suçlu bulunur. Yörenin toprak peşinde koşan köylüleri, Mestan'ın ailesi, Yel Veli’nin ailesi ve yakınları kelepçelenerek kendilerine edilen küfürler, atılan taşlar ve pislikler, vurulan tekmeler eşliğinde "vatan hainleri, din düşmanları, Moskoflar" diye bağıran çarşı kalabalığının arasında kasabada gezdirilirler (Kemal, 1999: 203). Ağalar için her şey yolundadır. Çukurova'da yapılacak modern çiftlikler, kurutulacak Akçasaz bataklığından yükselirken, topraksız köylülerin ne gibi bir işlevi olabilirdi ki! Öte yandan dostu demirci Mustafa’yı öldürdüğü söylenerek içeri atılan Tellal, suçsuzluğu anlaşıldığında bu işi başına getiren Kurtboğa Ağası'nı öldürür.

Yerel otoriteler tarafından modernleştiği iddia edilen, romanın geçtiği toplumda kan davasının ortadan kalkması için erkeklerden barış kurulu oluşturmak istenir. Yeni ağaların arzulu davrandıkları bu kurulun asıl amacı, her iki aileyi sürdürmektir. Böylece yeni ağalar 
gidenlerin topraklarına rahatça konabileceklerdir. Aileler birbirlerini öldürdüklerini inkâr etseler bile vali, kaymakam, belediye başkanı, askeri erkan vb. bunu bilmektedir. Vali, "bunlar vahşi, bunlar hasta, deli, yalnız bilsinler ki, ne kadar canavar olurlarsa olsunlar hükümetimiz bu canavar derebeylerinin tepesine balyoz gibi iner" (Kemal, 1998: 183) demektedir. Barış kurulunun çok fazla rolü olmaz. Sermayenin yasaları ve buna göre biçimlenen toplumsal ilişkiler doğrultusunda zaman içinde kurul, işlevsiz kalır. Öyle de olur. Her iki kan davalı ailenin çocukları, değişen dünyanın nimetlerine ve gücüne yoğunlaşıp ardından da kendi aralarında iktisadi girişimlerde bulunurlar. Mustafa'nın oğlu Memet Ali, yanlarında tuttukları köylülerin gönderilmesi yönünde babaannesi Karakız Hatun’a karşı gelerek, traktörü ve diğer tarım aletlerini emek yoğun işlerin yerine koymayı başarır. Bir yandan yeni köyler ve çiftlikler kurulurken, diğer yandan fabrikalar için makineli tarımın geliri sermayeye dönüştürülür. Çeltikçilik, gelire gelir dememektedir. Memet Ali'nin, makine almak için tarla satmaya çalıştığı Ala Temir'e söyledikleri yaşananları özetler: "Para parayı büyütmezse, büyümeyen para ölüme mahkumdur. Para her gün her gün doğuracak, doğurmalı” (Kemal, 1998: 514).

Eserin ikinci cildinde Mustafa Bey’in yalnızlığg göze çarpar: "Memet Ali artık ilden hiç gelmiyordu. Birçok traktör sürücüsü göndermişti. Traktörler, batoslar, biçerdöverler, pulluklar, kötenler, atlar, inekler, öküzleri alıp götürmüşlerdi” (Kemal, 1999: 14). Mustafa Bey’in yanında Senem Karı dışında kimse kalmamıştır. Babasını Adana’ya gelmesi konusunda ikna edemeyen Memet Ali, kan davasını anımsayarak "yabanıllar, barbarlar" söylemiyle ara ara babasından bütün mallarını elinden alacak şekilde imza almaya gelip ilişkisini koparır (Kemal, 1999: 15). Çevredeki hareketlilik doğrultusunda Mustafa Bey’in trajedisi Derviş Bey’in dikkatinden kaçmaz: "Bir şeylerin çürüdügünün, koktuğunun, bittiğinin eksildiğinin farkındaydı. Derviş Bey’in içindeki boşluk günler geçtikçe çoğalıyor, azıtıyordu” (Kemal, 1999: 16). Oğlu Muzaffer bile Memet Ali ile ortak fabrika kurar. Sosyolojik açıdan ele alındığında, baba-oğul ilişkileri ve ataerkil otorite, yenilik kazanan geleneksel bir toplumun önde gelen sacayakları doğrultusunda hızla değişmektedir (Kıray, 1999b: 118). Diğer yandan aşiret ilişkileri değişirken emek yoğun çalışanlar için beyler tarafından sağlanan sosyal bakımı yerine getirecek güvenlik mekanizmaları, sosyal güvence modeli olarak söz konusu değildir ve bu durum, eserin birçok yerinde görülebilmektedir.

Erkek, iktidarını korumak için her yolu dener; insan öldürür, dağa kız kaçırır, karakolda işkence yapar, usulsüz bir şekilde devlet işini kötüye kullanır, çiftlik kurar, köylüyü sömürür, çoklu evlilik yapar, büyük toprakların sahibi olur, toprak gelirini kullanır, toplumsal cinsiyet rollerine dayalı iş bölümünü sürdürür, silah kullanır, kamu görevlilerini satın alır... Konaklarında yaşayanların dişarıda ve içeride nöbetçileri bulunur. Yanaşmalar karın tokluğuna çalışır. Dolayısıyla sermaye yalnızca erkeğe aittir. Bu sosyal ekonomik veriler, erkek egemen toplumu açıkça gözler önüne serer. Sermayenin erkek eli, ekolojik yapıyı da değiştirir. Yeni ağaların telaşı, bataklığın bir an önce kurutulup tapusunu almaktır. Topraklı ve topraksız köylüler, ağalar, beyler, "bu altın örneği topraktan, herkes, her gün bir parça koparıyordu. Ulu bir savaş vardı su altındaki bu verimli toprağın yöresinde. Herkes herkesin gözlerini oymaya hazırlanıyordu" (Kemal, 1999: 42). Sonuçta yeni ağaların hükmü sürecektir. 
Romanın sonlarına doğru satılan konağının yıkılmasına başlanırken Mustafa Bey için Derviş Bey harekete geçer: "Onu görmeli, on görmeliyim, neye mal olursa olsun bugün, bu perişanlıkta onu görmeliyim. Ölmüşse eğer, kurtlanmış şişmişse, onun cenazesini ben kaldırırım, en güzel törenlerle, yiğit, onurlu düşmanımın. O ölmekle benim de yarım öldü demektir” (Kemal, 1999: 557-558). Derviş Bey, yer yatağında kıvranan hasta Mustafa’yı görünce geri çıkar. Yerine modern bir çiftlik binası kurulması için satılan konağın yıkımı ilerleyince Mustafa Bey, Derviş’i bekler. O gün gelmez. Bakıcısı yaşlı kadınla vedalaşır, yola çıkar. Cansız bataklığa bedenini bırakır. Derviş Bey de Yusuf'u öldürür. Akyollu konağına uğrar. Konak yıkılmıştır. O da altındaki atı sürerek Ceyhan ırmağa doğru gider...

Kadınlar açısından bir değerlendirmede bulunmak gerekirse, romanda kadın karakterlerin büyük ölçüde yan karakterler olduğu net bir biçimde anlaşılmaktadır. Toplumsal alanda erkekler kadar görünür kılınmadıkları gibi, ataerkil yapıda tamamıyla erkeklerin kontrolündedirler. Öyle ki, "ataerkil sistem içerisinde erkekler ve erkeklik ideolojisi tarafindan ezilen, baskı altına alınan ve bir zaman sonra bu ezilmeyi içselleştiren kadınlar, sadece kendi cinsinden olanların bulunduğu bir ortamda bile kendisini rahat hissetmeyip deneyimlerini paylaşamadıkları" (Kepekçi, 2012: 69) sorunsalı romanda gözlemlenen bir gerçekliktir. Çoğunluğu oluşturan erkekler, hegemonik erkekliğin hem öznesi hem de nesnesi olurlar. Her iki romanda ortaya çıktığı gibi belli bir grup erkek azınlığı, güç ilişkilerine yön vermektedir. Zira "hegemonik erkeklik kavramı, nasıl olup da küçük bir azınlık erkeğin bütün iktidar ve güç pozisyonlarını ellerinde tuttuğunu; bunu nasıl meşrulaştırıp tahakkümü yeniden var edebildiğini açıklamaya çalışmaktadır" (Sancar, 2013: 32). Açıkçası bu sosyal gerçeklik, eserde eski ve yeni ağalar, köylüler, politikacılar ve kamu çalışanları üzerinden işlenir.

\section{Sonuç}

Üretim ilişkilerinin etkilediği toplumsal-politik süreçler, mekânsal değişiklikleri de beraberinde getirmektedir. Çukurova'da kültürel antropolojik ele alışla göçebe aşiretlerin, egemen olanın talepleri doğrultusunda toprağa yerleştirilmesiyle çadır yaşamı ve hayvancılık alanındaki uğraşlar tarımsal alana kayarken, toprağa yerleşiklik köy niteliğinde bir yaşamın kapılarını açar. Kuşkusuz ağaların ve beylerin güç sahibi oldukları toplumsal yapılarda, ekonomik unsurların belirlediği şekilde birbirinden toprağı ve topraktan elde edilen geliri kullanma yönüyle kalın çizgilerle ayrılmış toplumsal tabakalar bulunur. Aynı zamanda aşiretler ve geniş aileler üzerinden ilerleyen bir toplumsal işleyişte ataerkil düzen de sürdürülmektedir. Eski ağalar arasında yer alan romanın ana karakterleri Derviş ve Mustafa Beyler, etraflarında aşiretleri olmakla birlikte çiftliklerindeki geniş konaklarında birincil düzeydeki aileleriyle yaşamlarını idame ettirmektedirler. Eserde toplumsal bir güç olarak belirleyici oldukları dönemde, kasaba ileri gelenlerinin, yürütme konumundaki siyasi yapı ve bürokrasinin uzun yıllar desteğini görmüş bu ağaların dönemi kapandığında, dönüşen üretim ilişkileri içinde yeni ağa tipleri ortaya çıkmıştır. Bunlar, Anadolu'da özellikle kendi dinamiğinde ilk tarımsal kapitalizmin gelişme eğilimleri içinde yeni sermaye grupları olarak biçimlenirken, kendilerinden önceki ağa kuşaklarına göre daha geniş bir refaha sahiptirler. Burada altı çizilmesi gereken nokta, her iki toplumsal dönüşüm aşa- 
masında hegemonik erkekliğin hâkim unsur olmayı sürdürmesidir. Diğer yandan ortaya çıkan bir çelişki de şudur: Derviş ve Mustafa beyler yaşlanırken, geleneksel toplumlarda gördügümüz toplumsal statünün artmasının aksine, statü kaybıyla birlikte üretim araçları üzerindeki tasarruflarını, değişen koşullarda çocuklarına bırakmaları ataerkil yapının başka bir yöne evirilmesine sebep olmaktadır. Tarımsal kapitalizmdeki ilerlemeyle fabrikaların çoğalması, ekonomik gücün el değiştirmesi ve üretim süreçlerinin modernizasyonu hiç şüphesiz genç kuşak erkeklik hâllerine yansımaktadır. Mülkiyetin ve servetin erkek egemenliğinde olması, toprakları olmayan tarım işçilerinin bu sürecin dışına itilmesi çeşitli sosyal problemleri ortaya çıkarırken, kadınlar açısından çok daha eşitsizleştirici bir durumu toplumsal yapıda belirginleştirmektedir. Üretim ilişkilerine bağlı dönüşüm, toplumsal boyutlu olarak tüketim ve kullanım araçlarının çeşitliliğini de artırmaktadır. Örneğin, ulaşımda at önemini yitirirken Ala Temir'in altındaki gibi son model Mercedes ve Ford marka arabalar, toplumsal yaşamda statü göstergeleri olarak anlam bulur.

Diğer yandan romanda Türkmen gelenekleri hızla tükenmeye başlarken, bazı geleneklerse tam anlamıyla yozlaşır. Ayrıca erkeklerin iktidar oldukları toplumsal etkileşimlerin yanı sıra ekolojik döngünün değişimi (ekolojik yıkım) de yeni bir toplumsal gerçekliği inşa eder. Eski geleneksel mesleklerin, yani mekanik toplumda önemli işlevi olan mesleklerin (nalbant, demirci, tellal, yanaşma, köşker, saraç, yarıcı vb.) önemi azalır. At ve öküzle çiftçilik, yerini traktöre ve biçerdövere bırakır. Emek-sermaye çelişkisinin artmasıyla sosyal güvenlik arayışları eşliğinde Traktör İşçileri Sendikasının ortaya çıkışı, eserdeki bu tarihsel geçişi özetler. Toprak reformuna karşı olan yeni ağalar, yeni partilerin desteğiyle büyük çiftlik ve fabrikaların kurulmasından yana konum alırlar. Yaşar Kemal'in deyimiyle, yaptıklarından pişmanlık duymayan eli kanlı derebeyi atıkları, hiç kimseye güvenmemeyi gelenek edinmiş Derviş ve Mustafa Bey gibi tipler yeni koşulların altında kalmaya mahkûm edilmiş, artık bu modern dünya üstüne hiçbir şey bilmeyenlerin önemi bitmiştir. Dolayısıyla insanların hayatlarına yön veren değerler sistemi değişmiş, yeni sosyal etkileşim sistemlerine uyum gösteremeyenler anlam veremedikleri bir boşluğa sürüklenmiştir.

Değişen güç ilişkileri, hileli yollarla başlayan servet edinme savaşı her dönemin siyasetine eklemlenerek yerelde kendi otoritesini eril tahakküm temelinde inşa etmektedir. $\mathrm{Bu}$ sosyolojik gerçekliğin hegemonik erkeklik kısmını şöyle okumak mümkündür: Çukurova ağalarında gördüğümüz gibi hegemonik erkekliği örnekleyecek şekilde, toplumsal cinsiyet hiyerarşisinin egemen olduğu kamusal ve özel alanda toplumsal cinsiyet eşitsizliği, her koşulda erkek egemen sistemi meşrulaştırmak üzerine kurulu bir toplumsal yapıya içkindir. $\mathrm{Bu}$ gerçeklik, ağaların kendi aralarındaki ilişkilerinde, kasaba bürokrasisiyle sürdürdükleri etkileşimlerde, devletin ideolojik aygıtlarıyla girdikleri pratiklerde, ekonomi-politiğin değişen doğasının egemen yanında yer alarak kendi ideolojisini yeniden üretir. Kuşkusuz yaşanan süreç, ataerkil-geleneksel toplumsal etkileşim sistemlerinde ortaya çıkardığı anlam örüntüleri içinde kadınlara ve "güçsüz" erkeklere karşı kabul edilmiş bir erkeklik imgesini de yükler. Kamusal alandaki kurumların burada işlev sahibi olduğuna da değinmek gerekir. Aile, ekonomi ve siyaset kurumu gözetildiğinde bunların daha çok servet sahibi erkekleri teşvik eden bir dinamiği yarattıkları görülmektedir. 
Yaşar Kemal, umudun romancısıdır. Fakat bu özelliği, onu toplumsal gerçekliğin hegemonik erkeklik gibi arzu edilmeyen yanlarını başka eşitsizlikçi ilişkiler ağında, özellikle sınıfsal işlemesine ve bunlara tarihsel bir olgu kazandırmasına engel olmaz. Yazar; güçsüzlerin, sahipsizlerin, kimsesizlerin, topraksızların, adalet arayanların sözcülüğünü yaparak eserlerinde insanlık için umut aşılar. Romanda yoksul ve topraksız Tellal'ın ve Mestan'ın, zulüm abidesi hâline gelen yeni ağalardan bazılarını öldürmesi onur arama davranışı olarak gözler önüne serilirken, hegemonik erkekliğin kamusal ve özel alandaki gücü, servet sahibi erkeklerin artan rolüyle perçinleştirilip işlenir.

Yaşar Kemal'in yukarıda çözümlenen romanlarından hareketle denebilir ki, toplumsal tarihsel gerçeklere dayalı estetik değeri yüksek edebi metinleri erkeklik çalışmaları bağlamında da ele almak mümkündür.

\section{Kaynakça}

Aksu, N. (2003). Akçasaz'da yitenlerin ardından (S. Oğuzertem. Ed.) Geçmişten geleceğe Yaşar Kemal içinde (ss. 140-156). Adam.

Arık, E. (2016). Erkeklik çalışmaları (F. Saygılıgil. Ed.) Toplumsal cinsiyet tartışmaları içinde (ss. 231-248). Dipnot.

Arslan, A. D. (2019). Öteki, iktidar ve erkeklik ekseninde Murathan Mungan'ın “Binali ile Temir" ve "Dumrul ile Azrail” öyküleri. folklor/edebiyat Dergisi, 100 (25), 985-995.

Bourdieu, P. (2014). Eril tahakküm (B. Yılmaz. Çev.) Bağlam.

Bribiescas, R. G. (2021). Evolutionary and life history insights into masculinity and warfare: Opportunities and limitations. Current Anthropology, 62 (23), 38-53.

Carrigan, T., Connell, B., Lee, J. (1985). Toward a new sociology of masculinity. Theory and Society, 14, 551-604.

Connell, W. R. (2016). Toplumsal cinsiyet ve iktidar (C. Soydemir. Çev.) (2.bs.). Ayrıntı.

Çelik, G. (2016). "Erkekler de ağlar!”: Toplumsal cinsiyet rolleri bağlamında erkeklik inşası ve şiddet döngüsü. $\mathrm{Fe}$ Dergi, 8, 1-12.

Doorn, G. V., March, E. (2020). Hegemonic masculinity, gender, and social distance: The mediating role of perceived dangerousness. Journal of Gender Studies, 30 (3), 306-316.

Gedik, E. (2016). Bir tüketim kültürü ürünü olarak anti-kahraman erkek imajları. Vira Verita Dergisi, 4, 37-58.

Kandiyoti, D. (2015). Cariyeler, bacılar, yurttaşlar: Kimlikler ve toplumsal dönüşümler (A. Bora, F. Sayılan, F. Özbay, H. Tapınç, Ş. Tekeli. Çev.) (5.bs.). Metis.

Kemal, Y. (1998). Demirciler Çarşısı Cinayeti. Akçasazın ăgaları 1. (3.bs.). Adam.

Kemal, Y. (1999). Yusufçuk Yusuf. Akçasazın ă̆aları 2. (3.bs.). Adam.

Kepekçi, E. (2012). (Hegemonik) erkeklik eleştirisi ve feminizm birlikteliği mümkün mü? Kadın Araştırmaları Dergisi, 11, 59-86.

Kıray, M. (1999a). Toplumsal yapı toplumsal değişme. Bağlam.

Kıray, M. (1999b). Seçme yazılar. Bağlam. 
Laloğlu, P. (2018). Hegemonik erkeklik ve şiddet. Akademia Sosyal Bilimler Dergisi, 1, 393-397.

Lax, J. B., Mertig, A. G. (2020). The perceived masculinity of meat: Development and testing of a measure across social class and gender. Food, Culture\&Society, 23 (3), 416-426.

Lindisfarne, N., Cornwall, A. (2016). Dislocating masculanity. (2.ed.). Routledge.

Martin, D. L. (2021). Violence and masculinity in small-scale societies. Current Anthropology, 62 (23), 169-181.

Mutluer, N. (2013). Türkiye'de cinsiyet hâllerinin sınırları: "Namussallaştırma" (N. Mutluer. Ed.) Cinsiyet hâlleri içinde (ss. 14-30). Varlık.

Parın, K. (2019). Erkekliğin kitabı: Türk romanında erkeklik ve milliyetçilik (1908-1923). Söylem Filoloji Dergisi, 4 (2), 586-591.

Sancar, S. (2013). Erkeklik: İmkânsız iktidar: Ailede, piyasada ve sokakta erkekler. Metis.

Sezer Şanlı, A. (2019). Kültür çalışmaları ve feminizm bağlamında erkeklik çalışmalarına dair bir literatür analizi. Imgelem, 3 (5), 287-304.

Soysal Eşitti, A. (2020). Kürk Mantolu Madonna'da eril iktidarın yansımaları. Hacettepe Üniversitesi Türkiyat Araştırmaları, 32, 111-136.

Şeker, A., Özcan, E. (2021). Ekonomi-politik yönleriyle karşılaştırmalı roman analizi: Gazap Üzümleri, Demirciler Çarşı1 Cinayeti ve Yusufçuk Yusuf. Söylem Filoloji Dergisi, 6 (1), 79-91.

Tharaud, B. C. (2017). Çukurova Yaşar Kemal edebiyatının temelleri (T. Çulhaoğlu, Çev.) Yapı Kredi.

Türk, H. B. (2015). 'Şiddete meyyalim vallahi dertten': Hegemonik erkeklik ve şiddet (B. Yarar. Ed.) Şiddetin cinsiyetli yüzleri içinde (ss. 85-111). İstanbul Bilgi Üniversitesi.

Utanır Karaduman, A. (2020). İhsan Oktay Anar'ın romanlarında erkekler ve erkeklikler. Gaziantep Üniversitesi Sosyal Bilimler Dergisi, 19 (2), 526-542.

Yanıkkaya Aydemir, P. (2012). Antropolojide sinif ve toplumsal cinsiyet gerilim hattında Marksist ve feminist yaklaşımlar. İstanbul Üniversitesi Insanbilim Dergisi, 1 (2), 108-120.

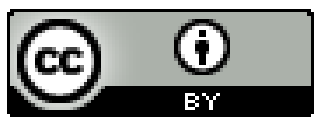

$\mathrm{Bu}$ eser Creative Commons Atıf 4.0 Uluslararası Lisansı ile lisanslanmıştır. (This work is licensed under a Creative Commons Attribution 4.0 International License). 